Asian Review of Social Sciences

ISSN: 2249-6319 Vol.8 No.1, 2019, pp. 16-19

(C) The Research Publication, www.trp.org.in

\title{
Holistic Student Development through Service Learning: An Experimental Study about Loyola College, Chennai, Tamil Nadu
}

\author{
S. John Kaviarasu ${ }^{1}$, J. Antony Anabarasan ${ }^{2}$ and J. Jai Dinesh ${ }^{3}$ \\ ${ }^{1 \& 3}$ Assistant Professor, School of Human Excellence, Loyola College (Autonomous), Chennai, Tamil Nadu, India \\ ${ }^{2}$ Assistant Professor, School of Service Learning, Loyola College (Autonomous), Chennai, Tamil Nadu, India \\ E-Mail: johnkavia@gmail.com, antonyanbu2015@gmail.com,jaidineshj@gmail.com
}

\begin{abstract}
Service Learning enhances and intensifies classroom learning which paves the way for practical community-based problem solving skills to students. The context of Service Learning at Loyola College, Chennai offers students an opportunity to explore the connections between the theoretical realm of the classroom and the practical needs of the community. In this connection, School of Service Learning at Loyola College is making the students to reflect about the experience in order to maximize the benefit of service in learning experiences. Therefore, this is an important process that links Service and academic learning. At the next level, it really motivates students to be human and also humane. Exposure to urban poor in the informal settlements of Chennai city makes undergraduate students of Loyola College to become aware about the issues faced by urban poor. Post graduate courses students gain exposure on rural interior villages which makes PG students to realize stark naked realities of the rural folk. Cognitive development is assured through formal Learning and teaching in the classroom by their respective teachers. Theoretical and Conceptual teaching could not provide holistic knowledge to students. This requirement is beautifully addressed by the School of Service Learning through its various activities and programmes with the constant guidance of professional social workers and Management.

Keywords: Holistic Development, Cognitive Development, Formal Learning, Service Learning, Humane, Informal Settlements, Urban Poor, Rural Folk, Intellectual Development
\end{abstract}

\section{INTRODUCTION}

To be happy is the pursuit of any normal human being. This happiness comes from giving (Steve Taylor (2015) and sharing. That is what is being imbibed in the hearts and minds of the undergraduate students, through Loyola College's Department of Service Learning. As a first step to achieve this goal, the students are made to reach out to the urban poor people living in slums and learn from them, the stark realities of life and develop the critical consciousness.

As Dr. A.P.J. Kalam remarked while talking to the students "Today's students are the future pillars of the nation", every educational institution in India has the bounden duty to shape its students' character. Honoring this commitment, Loyola College, and other educational institutions run by the Jesuits in the world, has the development of people and a Learning society as the fulcrum on which their whole education programme swirls.

\section{THE NEED FOR SERVICE LEARNING}

From the perspective of Loyola College Service Learning experience, it is understood that Service Learning is needed mainly for four reasons.

1. Students need to be enhanced in order to plan the development of the nation, to which he/she belongs.

2. Students are to be enabled so as to understand day to day contemplations of urban and rural poor.

3. Students need to be inspired to strongly influence the economic policies chalked out by the policy makers to devise suitable, need-based and developmental plans for the people, particularly, the poor living on the fringes and margins.

4. Students are to be facilitated to plunge into action for taking up correct methodologies for addressing the issues and problems of the poor people and gradually empowering them with need-based development.

\section{SERVICE LEARNING AND JESUIT HIGHER EDUCATION INSTITUTIONS}

Right from the year 2001, Service Learning has been made mandatory in Loyola College, Chennai and it has become one of the integral formations of students. This component of Service Learning creates a thirst for Service in the hearts and minds of the students. Through the department of Service Learning, the college aptly provides good opportunity for all students to enter the academic campus to become more fully developed human beings, 'having heartfelt minds and mindful hearts' (Maxwell, 1976 in McHenry, 2009, p32). The Service Learning makes students to keep in touch with the issue inflicted masses and enable them to become socially concerned, which in turn goads them on to develop interest for serving poor and needy in our society and later to "leave the college as better human beings' (Lewis, 2007,p(i)).

\section{A. Marking a Real Difference through Service Learning}

Honnet \& Poulsen (1989) says that Service, combined with Learning, adds value to each and transforms both. Service Learning at Loyola College has been designed to expose students to rightly understand the rural and urban poor, populace of the state. Students of undergraduates are exposed to informal settlements to understand the urban 
poor and students of postgraduates are exposed to rural areas to understand the rural populations and the living conditions through having a week long rural camp experience. In this way, Service Learning inspires and educates students to pursue their goals with an open mind. The practice of Service Learning at Loyola College gives the students the chance to apply what they have learned in the classrooms to real life situations. Loyola students, who participate in Service Learning, specifically teach them on social responsibilities.

For example, as students work as a team in the community, they learn that they can be responsible for making great things happen. When they retrospect on what they have done, they realize that it is actually helping fellow member in the society. Participating in Service Learning impart non academic skill upon students to build holistic personalities. As students work in a real, crisis-ridden setting either in urban slums or in rural areas, they imbibe skills related to projects volunteering and crisis resolutions. Service Learning helps in making a difference and helps students to reflect upon the effects on such emancipatory endeavors. As John F. Kennedy said, "If one person can make a difference, then everyone should try" is the mantra of Service Learning that is etched in the minds of all the students, who enter the portals of Loyola College, Chennai. "The campus environment provides opportunities for each student to obtain social awareness and selfless interest towards others". This maxim of Gandhiji has been driven home through the hearts of students, when they enter the Department of Service Learning, and motivates them to take up services / outreach programmes in order to help the needy and poor.

\section{B. Loyola Service Learning: Making of Men and Women}

Besides imparting cognitive skills among students, the institution promotes many aspects necessary for students' growth as people, who could think about the need of others to address.

Higher education has an important objective to spread across our society, because today's students will be tomorrow's leaders. While they need to demonstrate key skills and share knowledge to effectively enact those roles as responsible teachers, good policy makers, wonderful planners, service oriented doctors, environmentalists, engineers, business managers, faith leaders, honest politicians, good citizens, social activists, caring parents and compassionate neighbours, they must also make a firm commitment to carry them out. In this way, the School of Service Learning strives to significantly achieve the holistic student development that could address the current challenges the sector and society keep on facing.

\section{Developing Students to be Mature and Moral}

The Service Learning development encompasses not only academic Learning, but also extracurricular learning of students with emotionally and morally contented persons. Service Learning has nuances of integrative learning process and development.

\section{Towards Students' Holistic Development}

The Service Learning syllabi, which is meticulously drafted in Loyola College for all the disciplines of subjects, is concentrated to bring about a change in students' attitudes and values. Learning that takes place outside the classroom through Service Learning, exposes the students to have the following.

1. Students are driven to experience openness and understand 'other-person' orientation;

2. Students, who are turned out to be more altruistic or self-transcending, are more likely to engage in sustainable behaviours.

3. These altruistic motives are uniquely influential to Loyola College students, who in turn play an important role in instigating them for social and scientific research careers.

4. Students get greater likelihood of civic involvement.

5. Students are happy in saying that they are exposed to learning and imbibing greater understanding of other societies and norms which are more egalitarian and gender neutral.

6. Students are channelized to greater and more positive attitudes toward equality and tolerance.

7. Interaction among fellow classmates and all strata of people in the slums and rural areas exposes students to new experiences.

8. Students get greater exposure and increased awareness towards understanding the status of the urban poor and rural masses of Tamil Nadu state.

9. Students are enabled to contribute their skills, energy and resources for the empowerment of the needy and those who are not, blessed with all amenities in life, like them.

10. Service learning is an important programme at Loyola and this helps to channel various resources from the students to the poor, paving the way for a better future.

\section{CHARACTERISTICS OF HIGHER EDUCATION}

1. Ushering in holistic student development is the hallmark of higher education, which is a time of transition and change in which students grapple with identity and intimacy Students in higher education confront new ideas and ways of thinking as they interact with students from other backgrounds.

2. Mature students may be at a different developmental stage, but they are still in a turbulent evolution period in which existing views are challenged and identities are re-made. So students should not only deconstruct old meanings but also reconstruct a sense of purpose in their own lives that integrates expanded perspectives and worldviews. All these are clearly addressed by exposing the students to Service Learning, while they are in the formation of Learning. 


\section{CHANGE WITHIN TO THE CHANGE OUTSIDE}

Students of MA English Literature, after doing their Service Learning programme, have pointed out, "Ignorance is the root cause for all evil. To wipe out our ignorance in today's India and to enlighten young minds with social consciousness is the chief goal of "Service Learning programme". Amala Deepika (09-PEL-012), from her experience, remarked thus, Service Learning Programme has laid a strong foundation to achieve the goals of Service Learning, raking up my mind, to ask myself various questions of the following:

1. Do I owe my country? If so what?

2. Who is a good leader? Is there an ideal leader?

3. What is my part?

4. What can I do now?

5. Should I stoop to the status quo?

$6 . \quad$ Is theory practical?

7. Is change possible?".

Ms.Oliviesu, who was a student of M.Sc Zoology pointed out, I quote, "the whole Service Learning camp turned out to be a completely new experience for me. I got to know many people and learnt how to adjust and also made new friends. Besides all these, visiting villages and interacting with the villagers was a good Learning experience for me. She asserts that "though I agree there was a communication problem, since I am not from this state and unfortunately I am not at all linguistic, so it was quite hard for me to interact with people there, yet I now realize how people can live happily with minimum facilities. I was made more aware about the rural lives about which I was naïve". Ms. Oliviesu describes an experience of a village visit as "when we entered a village, I was quite taken aback by the way they welcomed us, utter strangers, with open arms, which was really a soul touching experience. I would love to say the Service Learning trip was a blessing in disguise for me". Loyola College is doing a yeomen job by offering Service Learning camp which makes the students with social morality.

The above two experience, clearly speak that this is the beginning of change and change within, is the first step to the change outside.

\section{VIEWS OF LOYOLA STUDENTS ABOUT SERVICE LEARNING}

1. It brings awareness among student fraternity and channelizes them towards serving the underprivileged.

2. It does create an opportunity for innovation and look at life in a very constructive way.

3. It is a platform by which students get to know about the problems of the fellow poor citizens and learn to address them in an appropriate way.

4. It helps students to journey within and without so as to be able to contribute their share in the promotion of justice and human values.
5. It enables students to understand the sufferings of the most marginalized and underprivileged people and to empathize with them.

6. It develops the positive attitude among the student community and exhibits a proactive role in nation building.

7. Skill development is made in the areas of leadership, social analysis, community organisation, planning, public speaking and so on.

8. Value formation is achieved academic and social ethics teaching particularly on empathizing the poor, marginalized and other vulnerable sections of the society.

The above points clearly reveal and reflect that students become role models as "men and women for others" with the Jesuit charisma.

\section{FEEDBACK OF STUDENTS FROM SERVICE LEARNING RURAL CAMP EXPERIENCE}

1. Most of us, city-bred children, are spoilt with too much pampering at home. The Service Learning camp has made us self-dependent.

2. We learnt to handle all kinds of people, to stay calm and stable during the critical situations and manage them wisely.

3. It was an eye-opener for us, not to waste resources that we are fortunate enough to be provided with. We are determined not to be negligent of these graces and to use them optimally.

4. After completing a task, the satisfaction that we experienced was beyond expectation.

5. The Service "Learning has taught us to be critically conscious and strive for the development of the backbone of our country-villages" so that Dr. A.P.J. Abdul Kalam's dream of 2020 should become a reality.

\section{CONCLUSION}

Service Learning is an innovative strategy in Learning, conceived by Loyola College, Chennai that aims to develop the students into future leaders with a passion to serve the common man, especially, those hailing from the most marginalized sections of the society. Through this, the undergraduate and PG students are transported and placed in real life situations, among the poor in urban and village settings and made to work with them, in "Service Learning Camps". This exposure into the very lives of the interior village people and urban slum dwellers, interacting with them and listening to their stories of woe and constant fight for betterment and justice, makes the students come face to face with their abject poverty, their daily struggles to make both ends meet, the stigma and discriminations they face, and their resilience to remain happy and joyful, in spite of these myriad problems. The students are made to appreciate the cozy and comfortable lives they have been provided, with all the essential amenities, motivated to reach out to these people, contribute their mite to bring a bit of sunshine into the lives of these unfortunate fellow citizens. With the 
constant guidance of teachers in the classes and the motivation of professional social workers at the Service Learning Camps, the students' eyes and hearts are opened to the real India that lives in the villages and slums and transforms them into men and women with a great passion to live for others, thus making their lives also more meaningful in the long run.

\section{REFERENCES}

[1] Anderson, J. (2000). Learning in deed: Service-Learning and Preservice teacher education. Denver: ECS Issue Paper. Education Commission of the States.

[2] Bringle, Robert G. \& Julie A. Hatcher. (1996). Implementing Service-Learning in Higher Education. Journal of Higher Education, 67(2), 221-239

[3] Honnet, Ellen P. \& Susan J. Poulsen. (1989). Principles of Good Practice for Combining Service and Learning. Wingspread Special Report. Racine, Wisconsin: The Johnson Foundation, Inc.

[4] Jacoby, Barbara, and Associates. Service-Learning in Higher Education: Concepts and Practices. San Francisco, CA: Jossey-Bass, 1996.

[5] Kaviarasu, John S. \& Jaiprakash. (2015, September). Seasoning the Heart of Students through the Department of Service Learning (Outreach) at Loyola College (Autonomous), Chennai - A Case Study, BEST: International Journal of Humanities, Arts, Medicine and Sciences (BEST: IJHAMS, 3(9), 1-10.
[6] Kaviarasu, John S. (2015, October). Bridging the Education Divide by the Department of Service Learning (Outreach) of Loyola College, Chennai: A Case Study. European Academic Research, 3(7).

[7] Lewis, H. (2007). Excellence without a soul: Does liberal education have a future?. Public Affairs.

[8] Martínez, B., \& Martínez, I. (2015). Service -Learning and initial training of educational professionals. Profesorado: Revista de curriculum formación del profesorado, 19(1), 244-260.

[9] McHenry, L. (Ed.). (2009). Science and the pursuit of wisdom: Studies in the philosophy of Nicholas Maxwell. Walter de Gruyter.

[10] Parker J. Palmer \& Arthur Zajonc. (2010). The heart of higher education: A call to renewal, first edition, Jossey-Bass.

[11] Prentice, M. \& Robinson, G. (2010). Improving student learning outcomes with Service Learning. Washington, DC: American Association of Community Colleges

[12] Quinlan, K. M. (2011). Developing the whole student: leading higher education initiatives that integrate mind and heart. Leadership Foundation for Higher Education.

[13] Robert G. Bringle \& Julie A. Hatcher. (1996, March-April). Implementing Service Learning in Higher Education, The Journal of Higher Education, 67(2), 221-239, Ohio State University Press.

[14] Robinson, J. \& Torres, R. (2007). A case study for Service -Learning: What students learn when given the opportunity. NACTA Journal, $51(4), 2-8$.

[15] Tinto, V. (1997). Classrooms as communities: Exploring the educational character of student persistence. Journal of Higher Education, 599-623. 